\title{
Canadian In-service Teachers' Concerns, Efficacy, and Attitudes about Inclusive Teaching
}

\author{
Laura Sokal \\ University of Winnipeg \\ Umesh Sharma \\ Monash University
}

\begin{abstract}
The study examined concerns, attitudes, and teacher efficacy of 131 in-service, Kindergarten to Grade 8 teachers in three school divisions in Manitoba, Canada. Analyses were conducted to identify the relationships between teachers' background variables, their attitudes and concerns about teaching in inclusive classrooms, and their efficacy for inclusive teaching. In addition, potential effects of training in special education on teachers' concern level were examined. Participants who had undertaken some training in special education had lower degrees of concerns about teaching in inclusive classrooms. We discuss the implications of these findings and how addressing in-service teachers' concerns could enhance their attitudes about inclusive teaching and their overall teacher efficacy.
\end{abstract}

Extensive research suggests a worldwide trend toward inclusion, a practice where all children regardless of ability level are included in classrooms with their age-matched peers (Forlin, 2010). Inclusive educational practices were endorsed almost 20 years ago by the Salamanca Statement and Framework for Action on Special Needs Education (UNESCO, 1994) and are now evident in many countries worldwide (Wu, Ashman, \& Kim, 2008). Canadian schools are no exception. In 1982, the Canadian Charter of Rights and Freedoms guaranteed each citizen the right to an education without discrimination based on level of mental or physical ability. As provinces in Canada have entrenched rights to generate their own subordinate policies as they relate to education, provinces began drafting provincial legislation to ensure the tenets of the Canadian Charter of Rights and Freedoms were upheld in policies specific to their provincial context. The Manitoba government, for example, mandated inclusion as the preferred approach and defined it as

a way of thinking and acting that allows every individual to feel accepted, valued, and safe. An inclusive community consciously evolves to meet the changing needs of its members. Through recognition 
and support, an inclusive community provides meaningful involvement and equal access to the benefits of citizenship. (Manitoba Education, Training, and Youth, 2001, p. 1)

Whereas these policies were promising, they required the necessary infrastructure in order to be implemented effectively. Policy makers and practitioners are not always in agreement regarding inclusive education practices (Watkins \& D'Alessio, 2009), and this disconnect was exemplified by a mismatch between policy initiatives and teacher training about inclusive education in Manitoba classrooms. Although Manitoba schools began to integrate students with special learning needs into classrooms with their age-matched peers in the 1970s (Andrews \& Lupart, 2000), it was not until almost 40 years later, in 2008, that pre-service teacher education programs in Manitoba were required to include mandatory "Special Education" courses in their teacher education curricula. It can be assumed that in-service teachers who started teaching prior to 2008 were less likely to have completed necessary training in special or inclusive education.

In order for Canadian schools to fulfill their mandate to provide equal educational opportunities for all children, we must consider the distinct and special role of classroom teachers. Research has shown that teachers are among the most influential factors affecting student success (e.g., Rivkin, Hanushek, \& Kain, 2005), especially with diverse learners (Forlin, Cedillo, Romera-Contreras, Fletcher, \& Hernandez, 2010; Timberley \& Alton-Lee, 2008), yet the essential attributes of effective inclusive classroom teachers remain elusive.

\section{Attitudes Toward Inclusion}

Research has suggested that teachers' attitudes are a significant determinant of success in inclusive classrooms and that teachers' attitudes affect their behaviours, in turn influencing the classroom climate and students' opportunities for success (e.g., Avramidis \& Norwich, 2002; Cook, 2002; Jordan, Schwartz, \& McGhie-Richmond, 2009; Silverman, 2007). Mittler (2003) showed that the negative attitudes toward inclusion held by teachers, parents, and administrators were the most significant barriers to successful inclusion. Forlin and Hopewell (2006), and Andrews (2002), therefore, suggested that teacher development programs have a key role to play in fostering attitudes that support inclusion.

\section{Teaching Efficacy in Inclusive Settings}

A second factor shown to affect teacher effectiveness in inclusive classrooms is teaching efficacy. Gibson and Dembo (1984) proposed that teaching efficacy consists of two components: general teaching efficacy and personal teaching efficacy. General teaching efficacy refers to teachers' belief that external influences can be overcome by good teaching. Personal teaching efficacy refers to teachers' beliefs in their ability to bring about change in a student (Gibson \& Dembo, 1984).

Several authors have argued that teaching efficacy is a context-specific construct (e.g., Tschannen-Moran \& Woolfolk Hoy, 2001) and that it varies across participants (Ross, Cousins, \& Gadalla, 1996) and across different student groups (Raudenbuch, Rowen, \& Cheong, 1992). In other words, a teacher who is highly efficacious in teaching mathematics may not be equally efficacious in teaching all other subjects (e.g., English). Tschannen-Moran and Woolfolk Hoy (2001), therefore, proposed that teaching efficacy should be measured in relation to specific teaching tasks in contextual classroom situations. Other research has supported this stance. For example, Smith (2000) found that even teachers who reported higher teacher efficacy for teaching children with mild special learning needs reported lower teacher efficacy when asked about 
teaching children with severe disabilities. Given that many students graduate from teacher education programs feeling unprepared to teach children with diverse needs (Forlin, Keen, \& Barrett, 2008; Glazzard, 2011), it stands to reason that these teachers may demonstrate a reluctance to teach in inclusive settings (Jordan et al., 2009) and will continue to hamper progress in schools as it relates to inclusive education (Atkinson, 2004; Forlin, Loreman, Sharma, \& Earle, 2009). Pindiprolu, Peterson, and Bergloff (2007) found that teachers who felt unprepared for inclusive classrooms desired professional development in the area of specific teaching strategies in order to feel more prepared.

Wertheim and Leyser (2002) suggested that instruction about and practice with specific teaching strategies for effective inclusion should be key components of teaching development programs. They contended that these types of professional development are effective in the enhancement of teacher efficacy beliefs.

\section{Teacher Concerns about Inclusion}

A third factor, one that has received far less attention in terms of its relationship to teacher effectiveness in inclusive classrooms than has teacher attitudes or teacher efficacy, is the role of teachers' concerns. Research has indicated that both pre-service and in-service teachers have concerns about inclusion, such as the lack of time they have for other students or a lack of adequate resources for effective inclusion to take place (Forlin \& Chambers, 2011; Horne \& Timmons, 2009). Sharma, Forlin, and Loremen (2008) suggested that courses on inclusive education are not always adequate to decrease these types of teacher concerns. However, they found teachers' concerns could be addressed when course content focused on legislation and resources that were in place to support inclusion.

\section{Relationships Between Teacher Attitudes, Efficacy, and Concerns}

While little research has examined attitudes, teacher efficacy, and concerns together, research that has examined two or three of these variables has resulted in a range of findings. Weisel and Dror (2006) found that teacher efficacy was the strongest predictor of positive teacher attitudes toward inclusion, and Chhabra, Srivastava, and Srivastava (2010) found a significant negative correlation between teacher concerns and attitudes. In their Irish study, Lambe and Bones (2006) found that when teachers were less concerned about availability of resources, their attitudes toward inclusion were positive. In contrast, Forlin and Chambers (2011) and Romi and Leyser (2006) showed that pre-service teachers actually had increases in their level of concerns during the inclusive education course, and that this change occurred during a period of stable positive attitudes about inclusion. These findings suggest that the relationships between constructs such as attitudes, teacher efficacy, and concerns are not necessarily linear and positive.

Thus, while the relationships between and among teacher attitudes, efficacy, and concerns about inclusion are complex, there is some evidence that these overlapping constructs are important elements of effective teaching for inclusion. What is less clear, however, is whether classroom experience alone can promote positive attitudes toward inclusion, teacher efficacy in inclusive teaching, and lower levels of concern about inclusion, and whether teacher education is necessary to foster these outcomes. Specifically, just how important and influential is professional learning about inclusive education to experienced teachers' attitudes, efficacy, and concerns about inclusion? 


\section{Current Study}

Although the research has shown that many teachers still graduate feeling ill equipped for teaching in inclusive settings (Forlin et al., 2008), in time these feelings of inadequacy may be ameliorated through on-the-job experience alone. Darling-Hammond and her colleagues (Darling-Hammond, Ruth, Andree, Richardson, \& Orphanos, 2009) found that only $15 \%$ of teachers named 'working with children with special needs' as their top professional learning priority, even though two-thirds of teachers surveyed had not received any professional learning about inclusive education during the past 3 years. Considered together, these studies suggest that experienced in-service teachers are less concerned about their need for professional development about inclusive practice than are novice teachers. The current research was undertaken to examine the relationship between participants' attitudes, teaching efficacy, and concerns about inclusive education and to identify the impact of a number of demographic variables, including level of teacher training, on these constructs. Therefore, the specific research questions which guided this inquiry were (a) What background factors predict Manitoban teachers' attitudes toward inclusion, teaching efficacy in inclusive classrooms, and concerns about inclusion? (b) Is there a significant relationship between teacher attitudes and teaching efficacy related to inclusive education? (c) How does training in special education influence teachers' concerns about inclusive education?

\section{Method}

\section{Participants and Data Collection}

The participants for this study were in-service teachers recruited from three school divisions in a central Canadian city totaling 99 schools where Kindergarten to Grade 8 classes were taught. After ethics approval, the school superintendents of three school divisions were approached to request permission for the researchers to contact their teachers. In each case, the divisions sent out letters through divisional intranet, requesting teacher participation. Teachers completed the consent procedures and responded anonymously to four instruments through FluidSurvey, an online site that stores data on a Canadian server.

\section{Instruments}

Demographics. We collected demographic information about participants including age, gender, highest level of education, training in special education, and whether they knew anyone with a disability. Two questions asked participants to indicate their knowledge and confidence levels on Likert scales. The first question asked participants to indicate their level of knowledge about the local policies and legislation that promote inclusive education in Manitoba using a 5point scale (nil to very high). The second question asked participants to indicate their level of confidence in teaching students with disabilities using a 5-point scale (very low to very high).

Attitudes toward inclusion. School Principals' Attitudes toward Inclusion (Bailey, 2004) was used to measure attitudes toward inclusion. Even though the scale was primarily designed for use with principals, the items in the scale are phrased in such a way that it can be used with any teaching population. Examples of statements are "Students with disabilities benefit academically from inclusion;" "Students with physical disabilities create too many problems to permit inclusion;" "Including students with special needs is unfair to classroom teachers who already have a heavy work load." The scale has 24 items, of which 15 items are worded negatively 
and 9 are worded positively. A participant can respond to each item using a Likert response format from strongly disagree (1) to strongly agree (5). Higher scores suggest a more favourable disposition to include students with disabilities in one's classroom. Bailey (2004) reported a reliability coefficient of 0.92 for the scale. A Cronbach's alpha of 0.86 was calculated for the current study, suggesting that the scale is reliable for the Manitoban context.

Concerns about inclusion. The 21-item Concerns about Inclusive Education Scale (Sharma \& Desai, 2002) measures participants' levels of concern about practical aspects of implementing inclusive education. Each item presents a concern (e.g., "I do not have the knowledge and skills required to teach students with disabilities;" "I will have to do additional work;" "It will be difficult to maintain discipline in class") and requires participants to express their degree of concern using a 4-point Likert scale $(1=$ not at all concerned to $4=$ extremely concerned $)$. The scale yields a total score ranging from 21 to 84 . Higher scores indicate greater concern about one's ability to implement inclusion. The scale was found to have an alpha coefficient of 0.91 (Sharma \& Desai, 2002) and has been used by researchers across different contexts (e.g., Bradshaw \& Mundia, 2006; Chhabra et al., 2010). The scale yields four factor scores. Reliability coefficients were calculated to determine the usability of the scales for Manitoba context: lack of resources $(\alpha=0.84)$, lack of acceptance $(\alpha=0.69)$, concerns about schools' declining academic standards $(\alpha=0.82)$, and concerns about increase in workload $(\alpha=0.76)$, as well as for the total scale $(\alpha=0.92)$. Alpha coefficients for all factors were adequate.

Teacher efficacy for inclusive practice. The Teacher Efficacy for Inclusive Practices scale (Sharma, Loreman, \& Forlin, 2012) was used to measure perceived levels of teacher efficacy. Following Tschannen-Moran and Woolfolk Hoy's (2001) proposal that teaching efficacy be measured in relation to specific teaching tasks in context, teacher efficacy was conceptualized in the current study as a teacher's capability to use a range of teaching practices to include students with a range of diverse learning needs into classrooms. Each of the 18 items can be rated using a 6-point Likert format $(1=$ strongly disagree to $6=$ strongly agree $)$. Higher scores indicate higher perceptions of sense of teaching efficacy to teach in inclusive classrooms. Examples of items include "I am confident in my ability to prevent disruptive behaviour in the classroom before it occurs;" "I am confident in dealing with students who are physically aggressive;" "I am confident in informing others who know little about laws and policies relating to the inclusion of students with disabilities." Sharma et al. (2012) reported the reliability (alpha coefficient) of the scale based on the original validation to be 0.89 , and the scale was found to be reliable across different contexts (Hong Kong, India, Australia, and Indonesia). Scale reliability for the current study was $\alpha=0.91$.

\section{Results}

\section{Demographics}

The majority of participants in this study were women $(n=118,87 \%)$ which matches closely the gender distribution of in-service teachers in Winnipeg, Manitoba, where $88 \%$ of $\mathrm{K}-3$ teachers, $81 \%$ of $\mathrm{K}-6$ teachers, and $71 \%$ of grades $7-8$ teachers are female (T. Price, personal communication, March 14, 2012). Approximately $60 \%$ of the participants were above the age of 40 years, and $10 \%$ of the teachers indicated that they were younger than 29 years. Forty percent $(n=55)$ of the participants indicated they had a family member with a disability, and a little less than $20 \%$ indicated they had a friend with a disability. 
Around $57 \%$ of participants $(n=74)$ had completed some form of training in special education either during or after their university teacher preparation program. It is important to note that the rest of the participants, which accounted for $43 \%$, had not completed any training in special education either during or after their university preparation. The average duration of teaching experience in our sample was 15 years (range 1-40 years). When asked to indicate their knowledge about local policies and legislation that support inclusive education in Manitoba, a majority (59\%) indicated they had 'good' or 'very good' knowledge in this area; approximately $9 \%$ of participants indicated that their knowledge in this area was 'poor.' When participants were asked to indicate their level of confidence in teaching students with disabilities, approximately half the participants $(n=78,58 \%)$ indicated their confidence as 'average,' approximately $6 \%$ of the participants $(n=8)$ indicated their confidence as 'high' or 'very high,' and a little over 38\% $(n=50)$ indicated their confidence as 'low' or 'very low.' The data indicated that an overwhelming majority (94\%) had taught students with disabilities during their teaching careers.

\section{Predictors of Teachers' Attitudes Towards Inclusion}

We conducted a simple linear regression to answer the first research question. Variables significantly correlated with participants' attitude scores (based on initial correlation analysis) were used to undertake regression: knowledge of local educational policies and acts, confidence level, and training in special education. A significant model emerged, $F(3,127)=12.8, p<.001$, which accounted for $21 \%$ (adjusted $\mathrm{R}^{2}$ ) of the variance in participants' attitude scores. Training in special education $(\beta=2.42, p=.05)$ and level of confidence in teaching students with disabilities $(\beta=2.78, p<.01)$ significantly explained attitude scores. This finding suggests that participants who had obtained some form of training in special education were likely to feel more positive about including students with disabilities in their classrooms. Also, participants who felt more confident in teaching students with disabilities were more willing to include students with disabilities in their classrooms.

\section{Predictors of Teachers' Teaching Efficacy to Teach in Inclusive Classrooms}

We conducted a simple linear regression to determine factors that contributed in shaping participants' teacher efficacy scores. The same three variables (i.e., knowledge of local educational policies and acts, confidence level, and training in special education) used to examine participants' attitude scores were used in the regression equation. A significant model emerged, $F(3,127)=14.30, p<.001$, which accounted for $23 \%$ (adjusted $\left.\mathrm{R}^{2}\right)$ of the variance in participants' teacher efficacy scores. Only confidence in teaching students with disabilities $(\beta=4.23, p$ $<$.001) significantly explained participants' teacher efficacy score. This finding suggests that as a participant's level of confidence in teaching students with disabilities improves, overall teaching efficacy to teach in inclusive classrooms improves.

\section{Predictors of Teachers' Concerns about Inclusion}

Two variables (confidence level and training in special education) correlated highly with overall concern mean scores. These two variables were used to undertake a simple regression. A significant model emerged, $F(2,130)=7.08, p<.001$, which accounted for $8 \%$ (adjusted $\mathrm{R}^{2}$ ) of the variance in participants' concern scores. However, only level of confidence in teaching students with disabilities $(\beta=.252, p<.01)$ significantly explained participants' concerns. This suggests that as participants' level of confidence in teaching students with disabilities improves they become less concerned about including such students in their classrooms. 


\section{Relationships of Concern, Attitude, and Teaching Efficacy Scores}

We computed a series of Spearman correlations to determine relationships between participants' concern scores and their attitudes and teaching efficacy. Use of non-parametric tests (i.e., Spearman correlation) was considered appropriate for the analysis because the sample size was small. The Spearman's rho revealed a statistically significant negative correlation between participants' concern scores and their attitude total scores $(r s[136]=-0.52, p<.001)$. Participants' concern scores explained $27 \%$ of the variance in attitude scores. A significant correlation was also observed between participants' concern scores and their teacher efficacy scores $(r s[136]=$ $0.28, p<.001)$. However, the magnitude of this relationship was not large and accounted for only $8 \%$ of the variance in efficacy scores. This means that as participants' degree of concern increased, they tended to feel less inclined to teach in inclusive classrooms, and their level of teaching efficacy declined.

A significant correlation between participants' attitude and teaching efficacy scores $(r s[136]=0.44, p<.001)$ was also found. The results revealed that as participants felt more confident in their ability to teach in inclusive classrooms, their attitude to teach in such classrooms improved. It is not possible to conclude from these findings that one factor influenced the other. However, it is quite evident from the findings that both these constructs are highly inter-related.

\section{Relationships between Training and Degree of Concern}

We conducted a series of independent $t$ tests to determine if there were significant differences in mean concern scores between participants who indicated they had completed some form of training in special education and those who had not. The results are presented in Table 1.

The findings indicate that training was associated with significant differences in participants' concern scores. Results were significant only for the total scale, Factor 2 (concerns about acceptance), and Factor 3 (concerns about declining academic standards). Participants with some training in special education $(n=74)$ felt less concerned overall compared to those without any training. Similarly, participants with some training in special education were significantly less concerned about lack of acceptance of students with disabilities (Factor 2) and lowering of schools academic standards (Factor 3) compared to those who had not received training. Relationships between training and the remaining two concern factors were not significant.

\section{Discussion}

Findings of the current study contribute to the body of knowledge about the relationship between teachers' attitudes, teacher efficacy, and concerns about inclusive education. Further, analysis of the effects of teacher education on all three variables, with particular attention to teacher concerns, provides evidence on which to base recommendations for addressing teachers'

Table 1

T-test Results Based on Training in Special Education and Mean Concern Scores

\begin{tabular}{|c|c|c|c|c|c|c|}
\hline \multirow[b]{2}{*}{ Factors } & \multicolumn{2}{|c|}{ Training } & \multicolumn{2}{|c|}{ No Training } & \multirow[b]{2}{*}{$t$} & \multirow[b]{2}{*}{$p$} \\
\hline & $M$ & $S D$ & $M$ & $S D$ & & \\
\hline Factor 1 - Resources & 2.50 & 0.53 & 2.66 & 0.51 & -1.21 & .227 \\
\hline Factor 2 - Acceptance & 1.87 & 0.53 & 2.15 & 0.51 & -2.97 & .004 \\
\hline Factor 3 - Academic & 1.76 & 0.53 & 2.07 & 0.67 & -3.05 & .003 \\
\hline Factor 4 - Workload & 1.87 & 0.64 & 2.04 & 0.69 & -1.41 & .162 \\
\hline Concern Total & 2.02 & 0.53 & 2.25 & 0.53 & -2.50 & .013 \\
\hline
\end{tabular}


concerns. We examined the relationship between teachers' attitudes toward inclusion, teacher efficacy, and concerns in Kindergarten to Grade 8 classroom teachers. These variables were strongly correlated and were explained by at least one background variable. It was found that teacher confidence explained teacher efficacy, teacher confidence and teacher training explained attitudes toward inclusion, and teacher training explained concerns about inclusion. It would seem logical then to suggest that the way to influence teacher attitudes and concerns directly (and teacher efficacy indirectly) is through teacher education.

Given the relative lack of research on addressing teachers' inclusion concerns, the next set of analyses investigated this variable. Sharma, Forlin, and Loreman (2007) suggested concerns may be more malleable to intervention at the teacher education level, citing the less abstract nature of concerns compared to attitudes. To examine this relationship between training and concern in detail, we examined four areas of teacher concern (resources, acceptance, declining academic standards, and workload) to see whether they were predicted by training. Training explained two areas of teacher concern (concern about acceptance and concern about decreasing academic standards). We found that teachers who had some degree of training in special education tended to express lower levels of concern about lack of acceptance and declining academic standards. However, because we found no relationship between training and the remaining two factors (concerns about lack of resources and concerns about increase in workload), we speculate that these are genuine teacher concerns that must be addressed by school leaders.

These findings indicate that although classroom-based concerns could be adequately addressed by teacher education, school-based concerns might not be addressed by teacher education alone (Erten \& Savage, 2012). For example, teachers can incorporate social-emotional learning lessons into class time to address (classroom-based) concerns about acceptance of students with differences. However, school-based budgetary decisions regarding scheduling teachers' release time to plan and meet about their students and the provision of adequate resources and materials to meet the needs of diverse learners are typically outside the teachers' decision-making power. Yet, these factors have been shown to be real concerns to classroom teachers. Classroom practice and policy decisions to address workload and resources must therefore work hand in hand to address different types of teacher concerns. Past research indicates that support in the form of extra time to plan teaching activities and to collaborate with colleagues can significantly improve educators' willingness to teach in inclusive classrooms (Sharma \& Desai, 2008). It may also be necessary to undertake school-based surveys to determine what extra resources teachers need to ensure students with disabilities are well supported in schools.

While providing extra resources to teachers and supporting them with their inclusive education efforts are necessary, a need to provide adequate professional learning programs to inservice teachers cannot be overstated. Given that $43 \%$ of teachers who participated in the current study had received no formal teacher training about inclusion, despite the average years of employment in the teaching force being 15 years (range 1-40 years), the need to address this situation is obvious. Although, since 2008, Manitoba has required that all teachers who become certified to teach have completed at least 66 contact hours of coursework about inclusion in their Bachelor of Education program, this policy does little to address the needs of teachers already employed within Manitoba schools. These findings mirror those of Heiman (2001), where 67\% of in-service teachers had taken no courses in inclusive education. Hence, the low level of teacher training about inclusive education found in our sample is not unique to Manitoba.

Heiman (2001) also found that teachers in inclusive settings were aware of their skill deficits and were eager to gain these skills through teacher professional development. Similar to our 
findings, Heiman found that being under-prepared for teaching in inclusive classrooms, heavy workload, and limited resources (facilities and assistance) were key concerns identified by teachers, and that professional development through in-servicing was viewed as a possible solution to some of these issues. Dart (2006) suggested that teacher training can decrease concerns about inclusion among teachers. Likewise, teachers and administrators in Chhabra et al.'s (2010) research recognized that specialized training is essential not only for successful teaching and learning to take place but also for the success of inclusion as a philosophy.

By addressing teacher concerns through training, we posit that teacher attitudes and teaching efficacy in inclusive settings will also be affected, given the strong correlation between these three variables. Smith (2000) stressed teacher training as a means to address low teaching efficacy with diverse students. Furthermore, Weisel and Dror (2006) showed that teacher training about inclusion contributed significantly to teachers' positive attitudes about inclusion. Overall, the research literature suggests that teacher education is an important mechanism for decreasing teacher concerns and enhancing teachers' positive attitudes and efficacy for inclusive teaching. However, the current study highlights the inconsistent effects of training on teachers' concerns. While some concerns about inclusion can be addressed through education, the findings suggest that teacher training alone will be insufficient to address teachers' concerns about workload and lack of resources in inclusive classrooms.

\section{Implications for Policy and Practice}

So what does effective in-service teacher training for inclusion look like? Guskey (2003) demonstrated that an essential element is "flowthrough" from training programs to classroom practices to student outcomes. In addition, in-service teachers need to have opportunities to identify and to work on topics that have utility in their own classrooms. Wilson and Floden (2003) added several other criteria such as the establishment of explicit relationships between theory and practice, instructors who have teaching experience in similar contexts, peer teaching and learning, and opportunities to reflect on the applications within their own classrooms. Finally, Male (2011) suggested that an essential aspect of effective training for in-service teachers is the promotion of cognitive dissonance provided by opportunities for teachers to reflect on their attitudes, to question their attitudes' basis, and perhaps change their attitudes.

Yoon, Duncan, Lee, Scarloss, and Shapley (2007) conducted a meta-analysis of 1300 studies and found that the most effective professional learning was 30-100 hours in duration, and spread over a period of 6-12 months. Programs such as these, in-house professional learning communities and ongoing courses, have been shown to be effective in statistically raising student achievement. In contrast, shorter professional development programs from 5-14 hours have been showed to have no significant effect on student learning. Based on these findings, DarlingHammond et al. (2009) provided a list of professional learning recommendations including that professional development should be intensive, ongoing, connected to practice, and should build strong relationships between teachers.

O'Gorman (2010) reported on an innovative professional learning program available to inclusive teachers in Ireland. This one-year program is university-based, taken during a one-year paid leave, and involves university-based course work including standard lectures and workshops. In addition, it involves practica in other schools and literature reviews and research projects about issues in the in-service teachers' home schools. The government of Ireland funds and is expanding this program, demonstrating its strong commitment to inclusive education. The 
Irish program is an excellent example of a program that meets the criteria for effective teacher education and is one that is likely to have positive "flowthrough."

Another model of inclusive teaching and learning being developed in Manitoba is the Three-Block Model of Universal Design for Learning (see Katz, 2012). This model is garnering growing interest from teachers, administrators, and academics in Manitoba, and several school divisions in Manitoba are currently implementing this model. In addition, the Manitoba Teachers Society has offered professional development opportunities based on this model, making it more accessible to both urban and rural teachers. The Three-Block Model includes systems and structures, instructional practices, and social-emotional learning. In terms of professional learning, this model of inclusive practice is introduced in-house at the school and divisional levels. Then, interested teachers are invited to follow up through professional learning communities where they can discuss and plan for inclusion in their own classrooms through the Three-Block Model. Facilitators are available to co-teach with the in-service teachers in order to address any concerns teachers have while implementing the model. Learning about inclusive teaching through this approach meets many of the criteria for successful professional development criteria put forward by Wilson and Floden (2003). In addition, through the three blocks together, it addresses the conditions of both school-based and classroom-based approaches necessary to move forward the inclusive education agenda (Erten \& Savage, 2012).

\section{Limitations}

Readers must be cautious while interpreting the results of our study. We looked at correlations across a number of constructs. While a higher degree of correlation suggests a change in level of one construct (e.g., concern) is likely to influence another construct (e.g., efficacy or attitudes), it does not confirm that the relationships between two or more correlated constructs are causal. Future experimental research can provide data to confirm if the relationships among the constructs are causal. For example, measuring levels of concerns, attitudes, and efficacy scores at the pre- and post-stages of a professional development program would provide some support to the causal relationships among different constructs.

\section{References}

Andrews, J., \& Lupart, J. L. (2000). The inclusive classroom: Educating exceptional children (2nd ed.). Scarborough, ON: Nelson Canada.

Andrews, L. (2002). Preparing general education pre-service teachers for inclusion: Web-enhanced case-based instruction. Journal of Special Education Technology, 17, 27-35. Retrieved from http://www.tamcec .org/jset/

Atkinson, D. (2004). Theorising how student teachers form their identities in initial education. British Educational Research Journal, 30(3), 379-394. doi:10.1080/01411920410001689698

Avramidis, E., \& Norwich, B. (2002). Teachers' attitudes towards integration/inclusion: A review of literature. European Journal of Special Needs Education, 17(2), 129-147. Retrieved from http://www.tandfonline .com/toc/rejs20/current\#.Udbjp0vFEmY

Bailey, J. (2004). The validation of a scale to measure school principals' attitudes toward the inclusion of students with disabilities in regular schools. Australian Psychologist, 39(1), 76-87. doi:10.1080 /08856250210129056

Bradshaw, L., \& Mundia, L. (2006). Attitudes and concerns about inclusive education: Bruneian inservice and pre-service teachers. International Journal of Special Education, 21(1), 35-41. Retrieved from http://www.internationaljournalofspecialeducation.com/

Chhabra,S., Srivastava, R., \& Srivastava, I. (2010). Inclusive education in Botswana: The perceptions of school teachers. Journal of Disability Policy Studies, 20(4), 219-228. doi:10.1177 /1044207309344690 
Cook, B. (2002). Inclusive attitudes, strengths, and weaknesses of pre-service general educators enrolled in a curriculum infusion teacher preparation program. Teacher Education and Special Education, 25, 262277. doi:10.1177/088840640202500306

Darling-Hammond, L., Ruth, C. W., Andree, A., Richardson, N., \& Orphanos, S. (2009). Professional learning in the learning profession: A status report on teacher development in the United States and abroad. San Francisco, CA: National Development Staff Council. Retrieved from http://www.learningforward.org /docs/pdf/nsdcstudy2009.pdf

Dart, G. (2006). "My eyes went wide open": An evaluation of the special needs education awareness course at Molepolel College of Education, Botswana. British Journal of Special Education, 33(3), 130-138. doi:10.1111/j.1467-8578.2006.00428.x

Erten, O., \& Savage, R. (2012). Moving forward in inclusive education research. International Journal of Inclusive Education, 16(2), 221-233. doi:10.1080/13603111003777496

Forlin, C. (2010). Developing and implementing quality inclusive education in Hong Kong: Implications for teacher education. Journal of Research in Special Educational Needs, 10, 177-184. doi:10.1111/j .14713802.2010.01162.x

Forlin, C., Cedillo, I., Romera-Contreras, S., Fletcher, T., \& Hernandez, H. (2010). Inclusion in Mexico: Ensuring supportive attitudes by newly graduated teachers. International Journal of Inclusive Education, 14(7), 723-739. doi:10.1080/13603111003778569

Forlin, C., \& Chambers, D. (2011). Teacher preparation for inclusive education: Increasing knowledge but raising concerns. Asia-Pacific Journal of Teacher Education, 39(1), 17-32. doi:10.1080/1359866X .2010 .540850

Forlin, C., \& Hopewell, T. (2006). Inclusion - the heart of the matter: Trainee teachers' perceptions of a parent's journey. British Journal of Special Education, 33(2), 55-61. doi:10.1111/j.1467-8578.2006 $.00415 . \mathrm{x}$

Forlin, C., Keen, M., \& Barrett, E. (2008). The concerns of mainstream teachers: Coping with inclusivity in an Australian context. International Journal of Disability, Development and Education, 55(3), 251-264. doi:10.1080/10349120802268396

Forlin, C., Loreman, T., Sharma, U., \& Earle, C. (2009). Demographic differences in changing pre-service teachers' attitudes, sentiments and concerns about inclusive education. International Journal of Inclusive Education, 13(2), 195-209. doi:10.1080/13603110701365356

Gibson, S., \& Dembo, M. H. (1984). Teacher efficacy: A construct validation. Journal of Educational Psychology, 76(4), 569-582. Retrieved from http://www.apa.org/pubs/journals/edu/index.aspx

Glazzard, J. (2011). Perceptions of the barriers to effective inclusion in one primary school: Voices of teachers and teaching assistants. Support For Learning, 26(2), 56-63. doi:10.1111/j.1467-9604.2011.01478.x

Guskey, T. R. (2003, April). The characteristics of professional development: A synthesis of lists. Paper presented at annual meetings of the American Educational Research Association, Chicago, IL.

Heiman, T. (2001). Inclusive schooling-Middle school teachers' perceptions. School Psychology International, 22, 451-462. doi:10.1177/0143034301224005

Horne, P., \& Timmons, V. (2009). Making it work: Teachers' perspectives on inclusion. International Journal of Inclusive Education, 13(3), 273-286.doi:10.1080/13603110701433964

Jordan, A., Schwartz, E., \& McGhie-Richmond, D. (2009). Preparing teachers for inclusive classrooms. Teaching and Teacher Education, 25, 535-542. doi:10.1016/j.tate.2009.02.010

Katz, J. (2012). Teaching to diversity: The Three-Block Model of Universal Design for Learning. Winnipeg, MB: Portage \& Main. Available from www.threeblockmodel.com /maudel.html

Lambe, J., \& Bones, R. (2006). Student teachers' perceptions about inclusive classroom teaching in Northern Ireland prior to teaching practice experience. European Journal of Special Needs Education, 21(2), 167-186. doi:10.1080/08856250600600828

Male, D. B. (2011). The impact of a professional development programme on teachers' attitudes towards inclusion. Support For Learning, 26(4), 182-186. doi:10.1111/j.1467-9604.2011.01500.x

Manitoba Education, Training and Youth. (2001). Supporting inclusive schools: A handbook for student services. Retrieved from http://www.edu.gov.mb.ca/ks4/specedu/ss/index.html

Mittler, P. (2003). Building bridges between special and mainstream services. Inclusion: theory and practice. Retrieved from http//www.eenet.Org.uk/theory 
O'Gorman, E. (2010). A four-ply model of professional development. In C. Forlin (Ed.), Teacher education for inclusion: Changing paradigms and innovation approaches. London: Routledge.

Pindiprolu, S., Peterson, S., \& Bergloff, H. (2007). School personnel professional development needs and skill level with functional behavioral assessment in ten Midwestern states in the United States: Analysis and issues. The Journal of the International Association of Special Education, 8(1), 31-42. Retrieved from http://iase-biz1.webs.com/publications.htm

Raudenbuch, S., Rowen, B., \& Cheong, Y. (1992). Contextual effects on the self-perceived efficacy of high school teachers. Sociology of Education, 65(2), 150-167. doi:10.2307/2112680

Rivkin, S., Hanushek, E., \& Kain, J. (2005). Teachers, schools, and academic achievement. Econometrica, 73(2), 417-458. doi:10.1111/j.1468-0262.2005.00584.x

Romi, S., \& Leyser, Y. (2006). Exploring inclusion preservice training needs: A study of variables associated with attitudes and self-efficacy beliefs. European Journal of Special Needs Education, 21(1), 85-105. doi:10.1080/08856250500491880

Ross, J., Cousins, J., \& Gadalla, T. (1996). Within-teacher predictors of teacher efficacy. Teaching and Teacher Education, 12, 385-400. doi:10.1016/0742-051X(95)00046-M

Sharma, U., \& Desai, I. (2002). Measuring concerns about integrated education in India. Asia and Pacific Journal on Disability, 5(1), 2-14.Retrieved from http://www.dinf.ne.jp/doc/english/asia/resource/z00ap /004/z00ap00401.html

Sharma, U., \& Desai, I. (2008). The changing roles and responsibilities of school principals relative to inclusive education. In C. Forlin \& M. J. Lian (Eds.), Reform, inclusion \& teacher education: Towards a new era of special education in the Asia-Pacific region (pp. 153-168). Abingdon, UK: Routledge.

Sharma, U., Forlin, C., \& Loreman, T. (2007). What concerns pre-service teachers about inclusive education? An international viewpoint. KEDI Journal of International Policy, 4(2), 95-114. Retrieved from http://eng.kedi.re.kr/khome/eng/kjep/guide.do

Sharma, U., Forlin, C., \& Loreman, T. (2008). Impact of training on pre-service teachers' attitudes and concerns about inclusive education and sentiments about persons with disabilities. Disability and Society, 13(7), 773-785. doi:10.1080/09687590802469271

Sharma, U., Loreman, T., \& Forlin, C. (2012). Measuring teacher efficacy to implement inclusive practices: An international validation. Journal of Research in Special Needs Education, 12(1), 12-21. Retrieved from http://onlinelibrary.wiley.com/journal/10.1111/\%28ISSN\%291471-3802

Silverman, J. (2007). Epistemological beliefs and attitudes toward inclusion in pre-service teachers. Teacher Education and Special Education, 30(1), 42-51. doi:10.1177/088840640703000105

Smith, G. (2000). Secondary teachers' perceptions toward inclusion of students with severe disabilities. NASSP Bulletin, 84, 54-60. doi:10.1177/019263650008461309

Timberley, H., \& Alton-Lee, A. (2008). Reframing teacher professional learning: An alternative policy approach to strengthen valued outcomes for diverse learners. Review of Research in Education, 32, 328329. doi:10.3102/0091732X07308968

Tschannen-Moran, M., \& Woolfolk Hoy, A. (2001). Teacher efficacy: Capturing an elusive construct. Teaching and Teacher Education, 17, 783-805. doi:10.1016/S0742-051X(01)00036-1

UNESCO. (1994). Salamanca statement and framework for action on special needs education. Paris: Author. Retrieved from http://www.unesco.org/education/pdf/SALAMA_E.PDF

Watkins, A., \& D'Alessio, S. (2009). Assessment for learning and pupils with special educational needs. A discussion of the findings emerging from the Assessment in Inclusive Settings project. RicercAzione Journal, 1(2), 177-192. Retrieved from http://www.erickson.it/Riviste/Pagine/Scheda-Rivista.aspx ?ItemId $=38538$

Weisel, A., \& Dror, O. (2006). School climate, sense of efficacy and Israeli teachers' attitudes toward inclusion of students with special needs. Education, Citizenship and Social Justice, 1, 157-174. doi:10.1177 $/ 1746197906064677$

Wertheim, C., \& Leyser, Y. (2002). Efficacy beliefs, background variables, and differentiated instruction in Israeli prospective teachers. The Journal of Educational Research, 96(1), 54-63. doi:10.1080 /00220670209598791 
Wilson, S., \& Floden, R. (2003). Creating effective teachers: Concise answers for hard questions. An addendum to the report, Teacher Preparation Research: Current Knowledge, Gaps, and Recommendations (2001), University of Washington. R-01-3.

Wu, W., Ashman, A., \& Kim, Y. (2008). Education reforms in special education. In C. Forlin \& M.-G. John Lian (Eds.), Reform, inclusion and teacher education: Towards a new era of special and inclusive education in Asia-Pacific regions (pp. 13-28) London, UK: Routledge.

Yoon, K. S., Duncan, T., Lee, S. W.-Y., Scarloss, B., \& Shapley, K. (2007). Reviewing the evidence on how teacher professional development affects student achievement (Issues \& Answers Report, REL 2007-No. 033). Washington, DC: U.S. Department of Education, Institute of Education Sciences, National Center for Education Evaluation and Regional Assistance, Regional Educational Laboratory Southwest. Retrieved from http://ies.ed.gov/ncee/edlabs/regions/southwest/pdf/REL_2007033.pdf

\section{Authors' Note}

Correspondence concerning this article should be addressed to Laura Sokal, University of Winnipeg, 151 Portage Avenue, Winnipeg, MB, Canada, R3B 2E9.

Email: lj.sokal@uwinnipeg.ca 